\title{
BELAJAR DARI KARAKERISTIK BANGSA JEPANG DALAM MENGHARGAI KEBUDAYAAN
}

\author{
Fatonah \\ Fakultas Ilmu Budaya Universitas Jambi \\ Jl. Lintas Jambi - Muara Bulian Km. 15, Kota Jambi \\ fatonah@gmail.com
}

\begin{abstract}
Learn From Japanese Characeristics In Respecting Culture. This study aims to produce qualitative data through extrinsic approach, ie the views and assessment of researchers from neutral eyeglasses to know and understand the Japanese life view, but it also aims to understand the characteristics of Japanese nation in culture. The focus of this research is the understanding of the Japanese society's life view and the characteristics of the Japanese in respecting the culture. Using a descriptive method in the realm of culture. In conclusion, the characteristics of Japanese society reflect a nation with high morality, strong mental and ethics, reflected in their values and norms of high esteem, polite language, friendly attitude, uphold loyalty, great sense of feeling and respect The rights of others, the Japanese are also obedient to law, order, discipline and very time-consuming and honest. Fond of reading and happy to study. All of these things have become a culture for them.
\end{abstract}

Keywords: Japan, culture, characteristics, values, norms, religion, religion, beliefs.

Abstrak: Belajar dari Karakeristik Bangsa Jepang dalam Menghargai Kebudayaan. Penelitian ini bertujuan untuk menghasilkan data kualitatif melalui pendekatan ekstrinsik, yaitu pandangan dan penilaian peneliti dari kacamata netral guna mengetahui dan memahami pandangan hidup bangsa Jepang, selain itu juga bertujuan untuk memahami karakteristik bangsa Jepang dalam budaya. Fokus penelitian ini adalah pemahaman tentang pandangan hidup masyarakat Jepang dan karakteristikarakteristik bangsa Jepang dalam menghargai kebudayaan. Dengan menggunakan menggunakan metode deskriptif dalam ranah kebudayaan. Simpulannya, karakteristik masyarakat Jepang mencerminkan bangsa yang memiliki moralitas yang tinggi, mental dan etika yang kuat, tercermin dalam nilai-nilai dan norma mereka junjung tinggi, memiliki budi bahasa yang sopan, sikap yang ramah tamah, menjunjung tinggi kesetiaan, sangat menjagga perasaan dan menghormati hak orang lain, bangsa Jepang juga taat pada hukum, tata tertip, disiplin dan sangat menghagai waktu dan bersikap jujur. Gemar membaca dan senang menuntut ilmu. Semua hal tersebut sudah menjadi budaya bagi mereka.

Kata Kunci: Jepang, budaya, karakteristik, nilai, norma, religi, agama, kepercayaan.

\section{Pendahuluan}

Bangsa yang besar adalah bangsa yang menghargai kebudayaan. Berbicara tentang kebudayaan berarti berbicara tentang manusia. Karena manusia tidak bisa lepas dari kebudayaan, sebagaimana pernah dikemukakan oleh Prof. Deddy Mulyana bahwa, "budaya kita secara pasti mempengaruhi kita sejak dalam kandungan hingga mati, bahkan setelah mati pun kita dikuburkan dengan caracara yang sesuai dengan budaya kita." Dengan kata lain, sebagai manusia kita terikat dengan kebudayaan yang kita anut dari mulai lahir (bahkan sebelum lahir) hingga wafat pun kita tidak bisa melepaskan diri dari kebudayaan yang kita anut.

Kebudayaan itu sendiri ada karena manusia. Manusialah yang menciptakan kebudayaan. Oleh karena itu manusia dan kebudayaan tidak dapat dipisahkan. Budaya berkenaan dengan cara hidup manusia. Seperti yang dikemukakan oleh Porter dan Samovar. ${ }^{1}$ bahwa, Manusia belajar berpikir, merasa, mempercayai dan 
mengusahakan apa yang patut menurut budayanya. Bahasa, persahabatan, kebiasaan makan, praktik komunikasi, tindakan-tindakan sosial, kegiatankegiatan ekonomi dan politik, dan teknologi, semua itu berdasarkan polapola budaya.

Dewasa ini banyak orang asing atau bangsa lain yang sengaja mempelajari semua hal tentang negara yang terkenal dengan nama negeri matahari terbit ini, baik itu dari segi pemasaran, teknologi, ilmu pengetahuan dan praktek manajemen khas Jepang, sejarah, bahasa, adat-istiadat dan budaya, maupun kepribadian hingga pada keyakinan dan pandangan orang Jepang terhadap religi (agama) atau kepercayaan. Semua dirasa penting dan sah-sah saja untuk dipelajari dan ketahui.

Homogen, modern, kaya budaya, teknologi yang canggih dan ekonomi yang maju tidak ada yang meragukannya. Sifat homogen kepribadian Jepang menjadikan negeri ini unik dan menarik. Keunikan tersebut selain tercermin pada aksara juga terlihat dalam pandangan mereka terhadap religi, kepepercaan, sikap, nilai dan norma-norma yang mendasari karakteris-karekteristik bangsa Jepang dalam menghargai kebudayaan.

\section{A. Manusia dan Kebudayaan}

Manusia dalam kesehariannya tidak akan lepas dari kebudayaan, karena manusia adalah pencipta dan pengguna kebudayaan itu sendiri. Manusia hidup karena adanya kebudayaan, sementara itu kebudayaan akan terus hidup dan berkembang manakala manusia mau melestarikan kebudayaan dan bukan merusaknya. Dengan demikian manusia dan kebudayaan tidak dapat dipisahkan satu sama lain, karena dalam kehidupannya tidak mungkin tidak berurusan dengan hasil-hasil kebudayaan, setiap hari manusia melihat dan menggunakan kebudayaan. Sebagaimana Soekmono mengatakan bahwa kebudayaan dan masyarakat tidak dapat dipisahkan. Kebudayaan akan selalu ada jika masih ada masyarakat pendukungnya. Masyarakat memiliki sifat tumbuh kembang sesuai jaman dimana masyarakat tersebut hidup. Kebudayaan akan terus tumbuh dan berkembang secara otomatis sesuai dengan perkembangan dan pertumbuhan masyarakat.

Sehubungan degan hal itu, kebudayaan menurut Edward B.Tylor sebagai keseluruhan yang kompleks meliputi pengetahuan, kepercayaan, kesenian, hukum, moral, adat dan berbagai kemampuan serta kebiasaan yang diperoleh manusia sebagai anggota masyarakat sedangkan, Cliffort Geert mendefinisikan kebudayaan sebagai suatu sistem simbol dari makna-makna. Kebudayaan mengacu pada suatu pola makna-makna yang diwujudkan dalam simbol-simbol yang diturunkan secara historis, suatu sistem gagasan-gagasan yang diwarisis yang diungkapkan dalam bentuk-bentuk simbolik yang dengannya manusia menyampaikan, melestarikan, dan mengembangkan pengetahuan mereka mengenai sikap dan pendirian mereka terhadap kehidupan. Senada dengan definisi tersebut, Ralp Linton memberikan definisi kebudayaan sebagai perilaku berpola yang dipelajari oleh setiap individu semenjak lahir. ${ }^{2}$ 
Budaya mempengarui dan dipengarui oleh setiap aktivitas manusia. Cara kita berpikirpun dapat tekondisikan dari kebudayaan itu sendiri. Budaya juga merupaka suatu alat untuk memahami perilaku manusia diseluruh bumi mana pun termasuk di negeri sendiri. Dengan memahami kebudayaan suatu negara, maka kita bisa memahami karakteristik bangsa tersebut. Memahami budaya orang lain akan mempermudah untuk berkomunikasi.

\section{B. Komunikasi dan Budaya}

Komunikasi dan kebudayaan merupakan dua konsep yang tidak dapat dipisahkan. Pusat perhatian komunikasi dan kebudayaan yang terletak pada variasi langkah dan cara manusia berkomunikasi melintasi komunitas manusia atau kelompok sosial. ${ }^{3}$ Pelintasan komunikasi tersebut menggunakan kodekode pesan, baik secara verbal maupun nonverbal, yang secara alamiah selalu digunakan dalam semua konteks interaksi.

$\begin{array}{rrr}\text { Komunikasi } & \text { merupakan suatu } \\ \text { proses 'ritual' } & \text { sebagaimana yang }\end{array}$
dikemukakan Carey ${ }^{4}$ yang menyatakan bahwa komunikasi merupakan suatu proses 'ritual' yang mengemukakan informasi melalui dua model, yaitu: (1) model transmisi, yakni model yang tidak secara langsung mengutamakan perluasan pesan dalam ruang, tetapi diarahkan untuk mengelola masyarakat dalam satuan waktu, model yang tidak mengutamakan tindakan untuk mengambil bagian dalam informasi, tetapi representasi dari pertukaran keyakinan; (2) sebagai pola dasar suatu 'ritual' untuk menarik orang lain agar turut serta dalam kebersamaan.

Komunikasi, baik dalam aktivitas simbolis, proses, maupun pertukaran makna, selalu ada dalam beberapa bentuk, salah satunya dalam komunikasi budaya. Komunikasi itu meminjam istilah Liliweri jelas 'serba ada' dan 'serba tempat', artinya komunikasi itu serba ada karena komunikasi itu ada dimana-mana.

Komunikasi dan kebudayaan seperti dua sisi mata uang yang sama pentingnya. Para ilmuan mengakui bahwa budaya dan komunikasi itu mempunyai hubungan timbal balik, seperti dua sisi dari satu mata uang. Budaya menjadi bagian dari perilaku komunikasi, dan pada gilirannya komunikasi pun turut menentukan, memelihara, mengembangkan atau mewariskan budaya. ${ }^{5}$ Edward T. Hall ${ }^{6}$ mengatakan "budaya adalah komunikasi" dan "komunikasi adalah budaya". Komunikasi dan budaya tidak bisa dipisahkan satu sama lain, karena masingmasing saling mempengaruhi. Budaya membentuk komunikasi, dan komunikasi membentuk budaya. Sehingga budaya menentukan cara seseorang berkomunikasi, misalnya bagaimana budaya orang Jepang dalam berkomunikasi dengan Tuhan atau Dewa maupun dengan antar sesama manusia dengan menggunakan simbol-simbol bahasa nonverbal dan verbal maupun melalui perentara jimat. Semua ritual keagamaan mereka selalu lekat dengan budaya dan komunikasi. Karena budaya berkenaan dengan cara manusia hidup. ${ }^{7}$ mengemukan bahwa manusia belajar berpikir, merasa, mempercayai dan mengusahakan apa yang patut menurut budayanya. Apa yang orang-orang 
lakukan, bagaimana mereka bertindak, bagaimana mereka hidup dan berkomunikasi, merupakan respon-respon terhadap fungsi-fungsi dari budaya mereka.

Budaya didefinisikan Keesing's ${ }^{8}$ sebagai 'system of knowledge that allows us to know how to communicate with others and to interpret others behavior." Pengertian budaya menurut Porter dan Samovar adalah, 'the deposit of knowledge, experience, beliefs, values, attitudes, meanings, hierarchies, religion, timing, roles, spatial relationships, concepts of the universe, and material objects acquired by a group of people in the course of generations through individual and group striving." Budaya merupakan tatanan pengetahuan, nilai, sikap, makna, hirarki, agama, waktu, peranan, hubungan, ruang, konsep alam semesta, objek-objek materi dan milik yang diperoleh sekelompok besar orang dari generasi ke generasi. Definisi-definisi tersebut menyatakan bahwa budaya adalah sistem pengetahuan yang memungkinkan manusia mengetahui bagaimana berkomunikasi dengan manusia lain, dan diperoleh dari keanggotaannya dalam suatu masyarakat.

Kebudayaan itu - meminjam istilah Liliweri - ibarat sebuah lensa. Dalam hal ini maksudnya, jika kita sedang memakai lensa untuk meneropong sesuatu maka kita akan memilih satu fokus tertentu dan dari fokus itu kita dapat membidik objek yang tepat. Objek tersebut menurut Liliweri, bisa manusia atau binatang, benda atau bahkan gagasan, termasuk gagasan tentang dunia sekeliling. Kalau kita memandang sesuatu dari sudut pandang kebudayaan maka kita akan menjadikan kebudayaan sebagai sebuah lensa seperti yang dimaksudkan Liliweri, artinya sebuah pandangan yang tepat, dan kebudayaan mengajarkan kepada kita untuk memandang sesuatu secara terfokus, secara tajam.

Dalam sudut pandang yang sederhana tidak sedikit orang awam yang memberikan arti bahwa kebudayaan itu adalah seni. Namun perlu diketahui bahwa kebudayaan bukan sekadar sebuah seni, kebudayaan melebihi seni itu sendiri karena kebudayaan meliputi sebuah jaringan kerja dalam kehidupan antar manusia. ${ }^{9}$ Kebudayaan itu mempengaruhi nilai-nilai yang dimiliki manusia, bahkan mempengaruhi sikap dan perilaku manusia. Dengan kata lain, manusia menurut Liliweri merupakan aktor kebudayaan karena manusia bertindak dalam lingkup kebudayaan. Seperti dipaparkan Porter dan Samovar. ${ }^{10}$ budaya berkesinambungan dan hadir dimanamana; budaya meliputi semua pengetahuan perilaku yang diterima selama suatu periode kehidupan.

\section{B. Pandangan Hidup Masyarakat Jepang Secara Umum}

Setiap manusia di dunia memiliki beberapa pandangan hidup dalam sistem kepercayaan dan sistem nilai terpenting, yang berkaitan dengan isu-isu filosofis tentang kehidupan dan mungkin berbeda antara budaya yang satu dengan yang lain. Seperti yang dipaparkan Mulyana, terdapat berbagai sistem kepercayaan dan sistem nilai lebih spesifik yang dianut seseorang mengenai berbagai aspek realitas, baik yang nyata ataupun yang abstrak. Kepercayaan pada dasarnya adalah suatu persepsi pribadi. Ia merujuk kepada pandangan bahwa sesuatu memiliki ciri-ciri atau kualitas tertentu, 
terlepas dari apakah hal tersebut dapat dibuktikan secara empiris (logis) atau tidak. ${ }^{11}$

Sedangkan nilai merujuk kepada kepercayaan yang relatif bertahan lama akan suatu benda, tindakan, peristiwa, fenomena (yang abstrak sekalipun) berdasarkan kriteria tertentu. Jika kepercayaan kognitif, maka nilai bersifat evaluatif.

Untuk mengetahui tentang pandangan hidup orang Jepang ini, mungkin bisa kita lihat dari watak dan kepribadian bangsa Jepang pada umumnya, sebagaimana dikemukakan oleh Danasasmita12 bahwa, ada empat karakteristik dari bangsa Jepang yang mendorong bangsa ini maju, yaitu:

Pertama, orang Jepang menghargai jasa orang lain. Hal ini dibuktikan dengan ringannya mereka dalam mengatakan arigatoo (terima kasih) ketika mendapat bantuan orang lain dan tidak menganggap remeh jerih payah orang lain meskipun bantuan itu tidak seberapa.

Kedua, orang Jepang menghargai hasil pekerjaan orang lain, dilambangkan dengan ucapan otsukaresamadeshita (maaf, Anda telah bersusah payah).

Ketiga, perlunya setiap orang harus berusaha, dilambangkan dengan ucapan ganbatte kudasai (berusahalah!).

Keempat, orang Jepang punya semangat yang tidak pernah luntur, tahan banting, dan tidak mau menyerah oleh keadaan yang terkenal dengan semangat bushido (semangat kesatria).

Bangsa Jepang pada dasarnya, memiliki kepribadian yang sangat dipengaruhi oleh semangat bushido yang sangat asketik, berdisiplin tinggi, dan menjunjung tinggi kode etik dan tata karma dalam kehidupan. Selain empat hal di atas yang dikemukakan oleh Danasasmita, ada dua hal lagi menurut Aulia Fadhli yang perlu ditambahkan, dua hal lain yang sangat lekat dan menjadikan bangsa Jepang memiliki karakteristik, sebagai berikut;

Kelima, Jepang adalah bangsa yang sangat menghargai tradisi dan memegang teguh kebudayaan yang telah diwariskan oleh pendahulunya.

Keenam, kehausan yang tak pernah puas akan pengetahuan. ${ }^{13}$

Dengan beberapa watak dasar inilah yang akhirnya membuat Jepang kembali muncul kepermukaan dan memegang kendali salah satu nahkoda dalam percaturan ekonomi internasional. Bahkan tidak hanya dari percaturan ekonomi namun juga dari segi kebudayaan Jepang sangat unggul. Ditengah terpaan derasnya globalisasi dunia mereka tidak menghilangkan kebudaan asli mereka. Kemajuan jaman bisa seiring dengan tradisi budaya leluhur mereka.

\section{Karakteristik-Karakteristik Budaya Jepang}

Budaya memberi indentitas kepada sekelompok orang atau bangsa. Bagaimana cara kita dapat mengidentifikasi aspek-aspek budaya Jepang yang menjadikannya berbeda dengan bangsa kita atau bangsa lain? Salah satunya adalah dengan menelaah aspek-aspek berikut.

\section{Komunikasi dan Bahasa}

Sistem komunikasi baik verbal maupun nonverbal akan membedakan suatu kelompok dangan kelompok lainnya. Fungsi utama bahasa adalah sebagai alat komunikasi atau alat interaksi yang hanya dimiliki manusia oleh karena 
itu komunikasi dan bahasa adalah dua hal yang tidak dapat dipisahkan. Ada banyak bahasa yang digunakan manusia di muka bumi ini, salah satunya bahasa Jepang. Basaha Jepang memiliki keunikan dan karakteristik tersendiri yang tidak terlepas dari budaya masyarakatnya. Mulai dari akasaranya hingga body language. Dalam tulisan bahasa Jepang bisa mengkombinasikan kanji, hiragana, kata kana dan romanji dalam satu kalimat atau pragraf dan syah-syah saja hal tersebut dilakukan dan terkadang konteksnya mengharuskan demikian.

Hal demikian menurut sejarahnya bermula melalui proses asimilasi dan adaptasi, segala sesuatu untuk yang masuk dari luar, lambat laun mengambil gaya Jepang yang hakiki. Diantaranya yang menjadi ciri khas dalam hal ini adalah mengenai pengembangan aksara Jepang pada masa Heian dan ritual keagamaan. Rumitnya tulisan Cina dengan kanji-kanjinya, membuat bangsa Jepang menyerderhanakannya dengan membuat huruf hiragana dan katakana. Hiragana digunakan untuk kata-kata yang asli Jepang dan katakana untuk kata serapan dari bahasa asing, misalnya bus dan taxi dalam bahasa Inggris dalam bahasa Jepang pengucapannya menjadi basu (バ)dan takusi (タクシー) dan ditulis dengan huruf katakana. Selain huruf hiragana dan katakana bangsa Jepang juga tetap menggunakan huruf kanji, untuk cara bacanya kanji terdapat dua cara, ada hatsu on (pengucapannya) diambil dari cara baca Cina yang disebut on yomi dan cara baca Jepang disebut kun yomi. Dalam bahasa Jepang, satu kalimat bisa menggunakan ketiga jenis huruf sekaligus (hiragana, katakana, kanji) dan tidak jarang juga bisa menjadi empat huruf bila ada kata yang ditulis dengan huruf romanji (huruf Latin) sperti yang sudah dikemukakan di atas dan syah-syah saja.

\section{Pakaian dan Penampilan}

Meliputi pakaian dan dandanan (make up) dan aksesoris yang melekat yang mengikuti. Seperti kita ketahui Jepang memiliki pakaian traditional khas yang sangat megah dan indah yang dikenal dengan nama kimono. Sebagai pembeda dari pakaian Barat (yoofuku) yang dikenak sejak zaman Meiji, orang Jepang menyebut istilah pakaian tradisional Jepang sebagai wafuku. Nama lain kimono disebut gofuku. Kimono ini biasanya dipakai berlapis-lapis, ada lapisan dalamnya bisa sampai dua lapis (hadajuban dan juban) dan kimono bahannya lebih tebal dan mewah. Biasanya harga kimono sangat mahal. Tiap tenunan, motif, warna, bentuk atau jenis memiliki makna tersendiri. Kimono untuk anak remaja yang belum menikah akan berbeda dengan yang telah menikah. Dari kimono juga bisa melihat status sosial pemakainya. Kimono biasanya dipakai pada kesempatan formal atau istimewa seperti pernikahan, upacara masuk sekolah, upacara seijin shiki (upacara kedewasaan buat remaja yang memasuki usia 20 tahun), upacara minum teh. Pakaian kimono tidak hanaya dipakai oleh wanita tetapi juga dipakai oleh kaum prianya. Orang tua maupun anak-anak. Pakaian kimono ini biasanya dipakai pada saat musim dingin. Sementara pada saat musim semi ketika cuaca hangat dan pada saat musim mau pun musim panas atau keseharian biasanya mereka menggunakan pakaian tradisional Jepang yang disebut yukata. Sama halnya seperti 
kimono bentuknya. Hanya saja yukata bahannya lebih tipis atau lebih ringan dari kimono. Harganya lebih terjangkau untuk semua kalangan dan pakaian dalamnya hanya satu lapis juban saja. Perlengkapan penunjangnya sama menggunakan obi yang melilit pinggang dengan berbagai kreasi yang indah. Memakai kimono atau yukata biasanya delengkapi dengan make up yang lebih tebal dan cantik sehingga memberi kesan anggun dan berkelas. Yukata bisa dipakai pada saat menikmati sakura, festival bunga (hana matsuri), festival obon, festival kembang api, tahun baru dan lain-lain.

Dewasa ini, meski Jepang sangat tren dengan pakaian harajuku maupun pakaian ala Barat namun pakaian tradisionalnya tidaklah diabaikan dan tidak tergrus oleh jaman. Hal ini bisa dilihat pada saat musim semi ketika sakura bermekaran tidak sedikit mereka menikamati musim bunga tersebut dengan menggunakan pakaian tradisonal mereka. Begitupun saat festival kembang api atau pada saat mereka mengunjungi kuil-kuil untuk bersembayang. Bahkan pakaian tradisonal mereka kimono dan yukata menjadi daya tarik tersendiri untuk wisatawan manca negara untuk mencoba memakainya dan mengabadikan momen-momen tersebut.

3. Makan Minum dan Kebiasaan Makan Minum (Termasuk Tata Cara Minum Teh)

Cara memilih, menyiapkan, menyajikan makanan dan minuman serta cara memakan dan minumnya sering berbeda anatara budaya yang satu dengan yang lainnya. Bangsa Jepang memiliki keunikan tersendiri dalam tatacara makan maupun minum. Misalnya tata cara makan masyarakat Jepang mengunakan sumpit. Dan sebelum makan orang Jepang akan membungkukkan badan sedikit dengan menempatkan tangan dipangkuan ketika duduk sambil mengucapkan kata "itadakimasu" ucapan ini seperti rasa syukur mereka atas makanan yang disajikan (kalau dalam agama Islam seperti bacaan basmallah) meskipun kata itadakimasi itu sendiri banyak diartikan "selamat makan". Pada saat makan cara yang tepat adalah mengangkat mangkuk nasinya (bukan piring seperti budaya Indonesia) menggunakan tangan dan mendekatkannya ke mulut kita dan saat memakannya dengan menggunakan sumpit. Sumpit juga digunakan untuk mengambil hidangan di piring (lauk pauk seperti daging atau sayuran). Selain itu sama seperti dalam budaya Jawa dianggap tidak sopan jika makan sambil mendengus, sendawa atau mengunyah hingga terdengar oleh orang lain. Namun untuk makanan tertentu yang berkuah sperti sup, ramen, udon dan lain-lain justru dianjurkan untuk menyeruput dengan suara yang keras saat sedang menikmatinya karena hal ini dianggap yang memakan sangat menghagai masakan yang disajikan, menganggap masakan tersebut lezat dan nikmat. Dalam budaya Jepang akan sangat tidak sopan jika makanan yang disajikan tidak dimakan sampai habis. Umumnya orang Jepang akan memakan sampai butiran nasi terakhir sebagi bentuk penghomatan terhadap tuan rumah atau penyaji. Setelah makan, orang Jepang tidak akan lupa mengucapkan kata "gochisousama deshita" yang berarti "terimakasih atas hidangannya" sebagai bentuk rasa terimakasih kepada orang yang menyajikan atau tuan rumah. 
Pada saat minum bersama-sama biasanya orang jepang akan memegang minumannya masing-masing sambil semua mengangkat minumannya untuk bersulang sambil mengucapkan kata "kanpai" yang pengertiannya sama dengan "cheers" dalam budaya Barat.

Upacara minum teh (cha-no-yu, sadoo atau chadoo) adalah ritual tradisional Jepang dalam menyajikan teh untuk tamu. Tradisi upacara minum teh barangkali adalah contoh paling tepat dalam menggambarkan pandangan hidup masyarakat Jepang secara umum. Menurut Beasley, Upacara minum teh dalam budaya Jepang berasal dari Budha Zen zaman dinasti T'ang, diperkenalkan kepada Jepang pada periode Kamakura. Dalam kaitan dengan keadaan ini cha-noyu (upacara minum teh) membuka peluang untuk mengedepankan selera estetika, untuk memperoleh nama di kalangan para tuan tanah feodal dan kalangan orang biasa tetapi kaya. Dari sisi politik, upacara minum teh membuka peluang untuk mengadakan pembicaraan rahasia. Sementara dari sisi sosial, mengingat tingginya harga yang dikenakan untuk minum semangkuk teh terbaik, mungkin diimpor dari Cina atau diramu di Jepang, upacara itu memungkinkan orang memamerkan kekayaan tanpa mencolok mata. ${ }^{14}$ Dalam sado atau cha-no-yu, tata cara yang diatur sangat halus dan teliti dalam menghidangkan dan meminum teh hijau, dalam tradisi upacara minum teh ini terdapat rangkaian seni yang mendalam, yang membutuhkan pengetahuan luas dan kepekaan yang sangat halus, selain itu juga mencerminkan kebersamaan dengan anggota keluarga atau kerabat. Upacara minum teh dalam budaya masyarakat Jepang selain bisa membantu meditasi, juga bermakna menjajaki tujuan hidup dan mendorong timbulnya apresiasi terhadap alam. Falsafah atau spirit dari cha-no-yu atau chadoo (upacara minum teh) ini adalah wa-ke-sei-jyaku. Yang berarti wa adalah kedamaian, harmoni manusia, sementara kei adalah hormat kepada yang lebih tua, rasa kasih sayang kepada teman atau yang lebih muda, dan sei adalah kebersihan dan kebenaran juga melambangkan hati manusia yang tenang dan santai, sedangkan jyaku adalah hal yang paling utama dari chadoo. Setelah teh dibuatkan, teh akan diberikan oleh sipembuat kepada orang pertama yang merupakan sebuah kehormatan bagi si penerima, sehingga teh tersebut harus diminum.

\section{Waktu dan Kesadaran akan Waktu}

Kesadaran akan waktu berbeda atara budaya yang satu dengan budaya yang lainnya. Sebagian orang pada budaya tertentu akan tepat waktu dan sebagian orang lainnya di budaya tertentu mungkin akan merelatifkan waktu. Dalam budaya Jepang, umumnya masyarakat Jepang sangat ketat untuk masalah waktu. Masyarakat Jepang memiliki kedisplinan yang sangat tinggi. Orang Jepang sangat menghargai waktu. Jika berjanji atau mengadakan pertemuan dengan orang Jepang jangan melakukan kesalahan dengan datang terlambat karena mereka sangat tepat waktu. Batas waktu terlambat hanya 2-3 manit, lewat dari 3 manit mereka akan meninggal kan tempat. Jika akan datang terlambat sebaiknya memberi tahu dari awal dengan mengemukakan alasan dan permohonan maaf bahwa anda akan datang sedikit terlambat. 
Mengutip dari Nufransa (dalam blog Nurfransa.wordpress.com) dirunut ke akarnya, ternyata sala satu budaya displin waktu ini bermula dari budaya bercocok tanam padi pada jaman dahulu. Negeri sakura ini memiliki empat jenis musim setiap tahunnya, sehingga mereka hanya dapat memanen padi sekali setahun. Dengan kondisi tersebut, para petani padi Jepang zaman dahulu dipaksa dan harus berdisiplin waktu agar padi yang mereka tanam sesuai dengan musim panennya. Bila gagal panenya itu, berarti mereka tidak bisa makan nasi selama setahun. Kebiasaan bertahun-tahun dalam bercocok tanam membuatnya menjadi suatu kebiasaan dan budaya bagi masyarakat Jepang.

Segala sesuatunya dibuat berdasarkan waktu yang telah diatur. Jadwal kereta, bus, kapal, pesawat dan transportasi lainnya dibuat secara tepat waktu sehingga membuat kepastian bagi orang yang hendak berpergian dari suatu tempat ke tempat lainnya. Di stasiunstasiun kereta mau pun di jalan-jalan di Jepang akan terlihat semua orang berjalan dengan ritme yang cepat. Tidak ada yang berjalan santai apa lagi di jam-jam sibuk, masyarakat Jepang berjalan terlihat seperti setengah berlari terutama di jamjam sibuk pagi hari.

\section{Penghargaan dan Pengakuan}

Menurut Harris dan Moran, suatu cara lain untuk menghormati suatu budaya dengan memperhatikan cara dan metode memberikan pujian bagi perbuatan-perbuatan baik dan berani, lama pengabdian atau bentuk-bentuk lain penyelesaian tugas. Bangsa Jepang termasuk bangsa yang pandai menghargai. Orang Jepang sangat menghargai orang lain. Misalnya, saat kita (orang asing) menyapa dan mengajak mereka mengobrol dalam bahasa Jepang, maka mereka akan membalas dengan sangat ramah dan sopan, entah kosa kata dan tata bahasa Jepang kita benar atau kurang sempurna ( dengan kata lain masih belepotan) mereka tetap sangat menghargai dan mereka tetap akan memuji dan memberi semangat, biasanya mereka akan mengatakan "nihongo ga jouzu desu ne" dengan senyum tulus dan ramah. Ucapan tersebut merupakan penghargaan atau pengakuan buat kita. Untuk karyawan yang kinerjanya bagus maka atasan orang Jepang tidak akan sungkan memberi penghargaan seperti kenaikan pangkat, gaji atau pun memberi bonus. Contoh lain adalah masyarakat Jepang sangat menghargai guru. Berbeda dengan kebanyak negara lain. Masyarakat Jepang sangat menghomati dan menghargai profesi guru. Sehingga mereka memanggil guru/dosen dengan sebutan "sensei" . Selain guru orang Jepang juga sangat menghargai dan menghormati orang yang lebih tua darinya. Sehingga tercermin dari pola bahasanya ada yang disebut dengan pola sonkeigo bentuk sopan digunakan untuk berbicara kepada orang yang lebih tua atau yang kedudukannya lebih tinggi dan pola kenjougo digunakan merendahkan diri pembicara didepan yang lebih tua atau kepada yang lebih muda dari pembicara untuk menunjukan kasih sayang.

\section{Nilai dan Norma}

Menurut Hariris dan Moran.15 sistem kebutuhan bervariasi, sebagaimana prioritas-perioritas yang melekat pada perilaku tertentu dalam kelompok. 
Mereka yang menginginkan kelangsungan hidup, menghargai usaha-usaha pengumpulan makanan, penyediaan pakaian dan perumahan yang memadai, sementara mereka yang mempunyai kebutuhan lebih tinggi menghargai materi, uang, gelar-gelar pekerjaan, hukum dan keteraturan. Jepang adalah menganut nilai-nilai dan norma yang tinggi. Jepang sangat menghargai waktu, pekerjaan, hukum dan keteraturan. Hal ini tercermin dari kehidupan masyarakat Jepang yang tertib dan teratur serta menjunjung tinggi nilai kejujuran. Jepang bisa dikatakan masyarakat yang paling jujur. Hal ini terlihat dari pola tingkah laku masyarakatnya yang sangat tertib mulai dari antri, mesekipun mereka sangat menghargai dan ketat dalam hal waktu tetapi mereka tidakan akan menyerbot atau mengambil yang bukan hak mereka. banyak contoh kasus misalnya ada barang yang tertinggal di kereta, bus atau di stasiun atau pun tempat umum lainnya tidak akan hilang, pemiliknya bisa kembali lagi ketempat semula meskipun sudah beberapa hari, biasanya barang yang ditemukan akan dititipkan kepada petugas stasiun, atau pada polisi. Alih-alih menggambil biasanya mereka dengan baik hati bersedia mengantarkan atau mengirim kepada alamat yang punya tanpa ada pamrih. Orang Jepang juga terkenal dengan keramatamahannya dan tulus. Jika bertanya tetentang alamat di Jepang pada penduduk atau orang Jepang, mereka dengan sopan dan ramah akan menjelaskan dan dengan suka rela mereka mengantarkan kita sampai ketempat yang benar-benar kita faham (seperti stasiun) atau ketempat tujuan. Jika berbelanja di
Supermarket, toko atau pun pasar saat mereka menyebutkan harganya dan kita kasih sejumlah uang seperti koin mereka benar-benar mengambil sesuai dengan harga yang tertera, tidak akan mengambil lebih dari uang yang kita sodorkan. Jika melaku kesalahan orang Jepang dengan jujur akan mengakui. Orang Jepang mengenal budaya malu oleh karena itu terkadang untuk mengatasi hal tersebut mereka mengambil langkah harakiri (bunuh diri ala Jepang).

Masyarakat Jepang juga memiliki norma dan nilai kolektivitas. Dalam suatu perusahaan manager muda tidak akan mengambil keputusan tanpa terlebih dahulu berkonsultasi atau memberitahu atasannya (para tetua di perusahan tersebut). Bukan berarti mereka tidak bisa mengambil keputusan tapi karena mereka menganut budaya kolektivitas menghormati (sedikit basa-basi) dan mengutamakan pemikiran yang lebih tua, yang sudah berpengalaman. Sebagaimana diungkapkan Mulyana bahwa, dalam masyarakat kolektivitas komunikasi antar manusia lebih rumit daripada dalam masyarakat individualis, untuk menjaga hubungan serasi dengan orang lain, orang kolektivitas cenderung berbasa-basi, kalau perlu berbohong, agar orang yang dihadapinya merasa senang atau setidaknya tidak tersinggung. Kolektivitas di Jepang ini lebih kuat daripada di Indonesia atau negara lain. Masyarakat koletivitas seperti Jepang ini menekankan komunitas, kolaborasi, kepentingan bersama, harmoni, tradis, kebaikan bersama, menjaga martabat dan terhindar dari rasa malu.

Norma lain yang juga dianut orang Jepang adalah rasa terimakasih dan balas 
budi. Hal ini tercermin dari sikap orang Jepang yang selalu mengucapkan terimakasih yang berlebih, seperti; "terimakasih, maaf sudah merepotkan anda" sambil membungkukan bandan. Hal ini akan diulang lagi ketika bertemu laki ke esokan hari atau sore harinya, mereka tetap akan mengucapkan lagi terimakasih terhadap apa yang sudah kita lakukan.

Melalui nilai dan norma keseharian masyarakat Jepang, bisa dilihat bahawa Bangsa Jepang terkenal sangat menjunjung tinggi moralitas nilai kesetiaan, ketulusan kejujuran dan pengabdian. Semua hal tersebut menjadi suatu yang sangat dihormati dan diagungkan.

\section{Kepercayaan dan Sikap}

Pandangan hidup suatu bangsa barkaitan erat dengan sistem kepercayaan dan keanekaragamannya. Kita telah menganut berbagai kepercayaan sejak kita lahir, yang ditanamkan oleh lingkungan kita, terutama keluarga. Misalnya, beberapa kepercayaan seperti; berdoa membantu menyembuhkan penyakit, tidak boleh mandi malam nanti kena reumatik, anak gadis tidak boleh duduk di depan pintu nanti jauh jodoh, memakai baju warna hitam tanda berduka, dan lain sebagainya.

Jepang merupakan salah satu bangsa di dunia yang sangat kuat menghargai tradisi dan kebudayaan yang diwariskan oleh nenek moyang mereka. Sepanjang sejarahnya, Jepang telah menyerap banyak gagasan dari negaranegara lain termasuk teknologi, adatistiadat, dan bentuk-bentuk pengungkapan kebudayaan. Gaya hidup orang Jepang dewasa ini merupakan perpaduan budaya tradisional di bawah pengaruh Asia dan budaya modern Barat. Hal ini tercermin dalam keseharian mereka yang sangat menghormati peninggalan sejarah hingga ke arwah nenek moyang. Kelebihan bangsa Jepang, kemajuan teknologinya tidak membuat mereka meninggalkan tradisi leluhur mereka, seperti festival obon, yang dimaksud untuk penghormatan dan pemanggilan arwah leluhur mereka pada waktu-waktu yang sudah ditentukan, upacara minum teh (sado atau cha-no-yu), seni merangkai bunga (ikebana), seni melipat kertas (origami), persembahan bunraku (teater boneka), teater kabuki, festival hanami, serta makanan Jepang dan lain sebagainya.

Berkaitan dengan kepercayaan dan sikap ini dalam penelitian tesis saya yang berjudul "Pemaknaan Jimat sebagai Simbol Religi bagi Mahasiswa Jepang" terungkap bahwa, Prinsip hidup orang Jepang menurut Sumiko menganut pemahaman pada "aminizumu" yaitu, hidup selaras dengan alam, diantaranya; percaya pada kekuatan alam, air, angin, api dan pepohonan. Sumiko memaparkan bahwa:

“orang Jepang umum tidak terlalu mementingkan agama, bayak yang tidak memiliki agama dan tidak mengerti tentang agama yang mereka anut. Berbeda dengan masyarakat di Indonesa yang beragama dan rajin beribadah. Di Jepang bebas mau mengikuti ritual agama mana saja. Seperti pada waktu prosesi pernikahan, boleh secara Kristen atau Budha, dan sehari-hari boleh mau mengikuti pemahaman agama apapun, boleh juga tidak memilikinya tapi pada saat meninggal biasanya menggunakan prosesi cara agama Budha. Orang Jepang pandangan hidupnya, umumnya menganut pemahaman aminizumu yaitu hidup selaras dengan alam, percaya pada alam, air dan pohon". ${ }^{16}$ 
Hal senada juga dikemukakan oleh Mai (21). Menurut Mai pandangan hidupanya adalah:

"berusaha menjadi selalu menjadi baik. Karena Tuhan itu ada begitu banyak, seperti matahari, angin, dan roh-roh manusia kalau sudah meninggal. Oleh karena itu ketika hidup harus menjadi orang baik.agar bisa menjadi Tuhan pada tingkatan yang lebih tinggi, kalau jahat atau berkelakuan jelek saat mati akan menjadi Tuhan pada tingkatan yang rendah. Hidup harus selaras dengan alam, karena Tuhan seperti matahari, angin, pepohonan dan lain-lain akan melihat.nanti bisa dikutukNya." 17

Meskipun Jepang merupakan bangsa yang modern dan maju dalam berbagai bidang, tetapi dalam religi atau kepercayaan, sikap dan pandangan mereka memiliki keanekaragaman, dari beberapa literatur dan hasil wawancara peneliti dengan beberapa orang Jepang dan orang-orang Indonesia yang pernah berhubungan atau dekat dengan orang Jepang, menghasil bahwa, sesungguhnya agama di Jepang dipahami dan dihayati dengan ringan. Nyaris semua aktivitas beragama di Jepang bersandar pada ide genze riyaku. Tidak peduli Budha atau Shinto. Genze riyaku adalah praktek beragama, beribadah, berdoa yang lebih ditujukan demi keuntungan duniawi. Sebagaimana dikemukan oleh Atniga Tayadih,18 "Agama di Jepang dipahami dan dihayati dengan ringan. Enteng. Santai. Tidak beda dengan memperlakukan dimensi kehidupan material yang lain." Meskipun dalam kehidupannya orang Jepang bisa melakukan beberapa ritual agama sekaligus namun tidak sedikit pula orang Jepang yang tidak mempercayai keberadaan Tuhan alias tidak memiliki pegangan agama apapun dalam keseharian mereka. Hal sebut dikarenakan sikap mereka yang santai dalam memanistasikan agama atau kerpercayaan berdasarkan ide genze riyaku.

\section{Proses Mental dan Belajar}

Sebagaimana kita ketahui beberapa budaya menekankan aspek perkembangan otak ketimbang lainnya. Sehingga menurut Harris dan Morgan, orang dapat mengamati perbedaanperbedaan yang mencolok dalam cara orang-orang berpikir dan belajar. Antropolog Edward T. Hall.19 berpendapat bahwa pikiran adalah budaya yang terinternalisasikan, dan prosesnya berkenaan dengan bagaimana orang mengorganisasikan dan memproses informasi. Kehidupan dalam suatu budaya tertentu menetapkan pahala atau hukum-hukum untuk mempelajari atau tidak mempelajari informasi tertentu, dan ini ini ditegaskan dan diperkuat oleh kebudayaan yang mereka anut. Maka masyarakat Jerman menekankan pada Logika, sedangkan masyarakat Jepang menolak sistem Barat. Seperti halnya, bangsa Jepang tidak menganggap perlu di sekolah-sekolah kurikulum agama. Bangsa Jepang lebih pada penanam karakter sejak dini untuk membentuk etika dan mental yang tangguh. Kita lihat misalnya contoh kasus, di sekolah-sekolah Jepang anak-anak harus kebersihan kelas, toilet dan lingkungan sekolahnya sendiri setiap hari sebelum proses belajar. Dalam hal ini, Anak- anak diajarkan memiliki tanggung jawab pada tugasnya dan niajarkan nilai kerja sama bergotongroyong. Berbeda dengan pola pendidikan di sekolah-sekolah Indonesia, membersihkan kelas atau toilet merupakan hukuman jika anak-anak melakukan kesalahan. Dari kasus diatas 
terlihat bahawa bangsa Jepang memanapkan nilai luhur untuk bertanggung jawab, menjaga keseimbangan dengan alam melalui kebersihan dan kerjasama team atau bergotong royong. Jika nilai-nilai tersebut diajarkan sejak dini maka anak-anak berlajar bertanggung jawab dengan demikian akan menjadi karakter mereka hingga dewasa dan membudaya selamanya.

Menurut Fadhli Minat dan kecintaan bangsa Jepang terhadap ilmu membuat mereka merendahkan diri untuk belajar dan memanfaatkan apa yang telah mereka pelajari. Ciri utama bangsa, yaitu kehausan yang tak pernah puas akan pengetahuan. Sebagai mana kita ketahui minat baca masyarakat Jepang sangat tinggi, sangat wajar jika bangsa Jepang sangat maju dalam bidang pendidikan.

Terkait dengan minat baca Jepang yang sangat tinggi ini, jika kita berada disudut mana pun kota-kota bahkan desadesa di Jepang, kita akan menemukan orang-orang yang diam sedang membaca, baik itu di taman, diterminal, di kendaraan umum seperti bus, kereta bahkan di pesawat pun kita akan melihat pemandangan yang tidak asing lagi, orang-orang Jepang sedang membaca buku atau membaca lewat kecangihan smart phone mereka. mereka tidak akan membuang atau membiar wakatu mereka terbuang percuma atau sia-sia tanpa memanfaatkan waktu sebaik mungkin. Membaca bagi kebanyakan orang Jepang bukan merupakan kegiatan yang dipaksakan, tetapi karena dalam diri mereka telah tertanam suatu sifat kebutuhan akan bacaan. Akibatnya, tidak heran bila kita lihat disudut mana pun aktivitas masyarakatnya membaca, dari generasi tua hingga generasi muda. Hal ini, sangat ber bedah jauh dengan bangsa kita Indonesia yang minat bacanya masih minim.

\section{Hubungan-Hubungan}

Bangsa Jepang sangan menghargai hubungan baik, jangankan kepada manusia, bangsa Jepang terkenal menjaga hubungan baik dengan, hewan, arwah nenek moyang (melalui festival obon) dan alam. Mereka hidup selaras dengan alam, tidak merusak alam. Seperti yang dipaparkan beberapa orang Jepang dalam penelitian tesis saya terdahulu. Prinsip hidup orang Jepang menurut Sumiko menganut pemahaman pada "aminizumu" yaitu, hidup selaras dengan alam, diantaranya; percaya pada kekuatan alam, air, angin, api dan pepohonan. Sumiko memaparkan bahwa: "orang Jepang umum tidak terlalu mementingkan agama, bayak yang tidak memiliki agama dan tidak mengerti tentang agama yang mereka anut. Orang Jepang pandangan hidupnya, umumnya menganut pemahaman aminizumu yaitu hidup selaras dengan alam, percaya pada alam, air dan pohon". ${ }^{20}$

Tidak beda dengan orang Jepang lainnya, Mai juga mengungkapkan bahwa; "berusaha menjadi selalu menjadi baik. Karena Tuhan itu ada begitu banyak, seperti matahari, angin, dan roh-roh manusia kalau sudah meninggal. Oleh karena itu ketika hidup harus menjadi orang baik.agar bisa menjadi Tuhan pada tingkatan yang lebih tinggi, kalau jahat atau berkelakuan jelek saat mati akan menjadi Tuhan pada tingkatan yang rendah. Hidup harus selaras dengan alam, karena Tuhan seperti matahari, angin, pepohonan dan lain-lain akan melihat.nanti bisa dikutukNya." 21

Dari dua pernyataan tersebut terlihat bahwa orang Jepang mempercayai 
adanya kehidupan setelah kematian (renkarnasi) oleh karena itu mereka sangat menjaga hubungan baik. Ketika hidup harus menjaga hubungan baik dengan manusia, hewan, alam dan roh nenek moyang agar dikehidupan selanjutnya bisa menjadi yang lebih baik lagi.

\section{Simpulan}

Budaya mempengarui dan dipengarui oleh setiap aktivitas manusia. Cara kita berpikirpun dapat tekondisikan dari kebudayaan itu sendiri. Budaya juga merupaka suatu alat untuk memahami perilaku manusia diseluruh bumi mana pun termasuk di negeri sendiri. Dengan memahami kebudayaan suatu negara, maka kita bisa memahami karakteristik bangsa tersebut.

Karakteristik masyarakat Jepang mencerminkan bangsa yang memiliki moralitas yang tinggi, mental dan etika yang kuat, tercermin dalam nilai-nilai dan norma yang tinggi, memiliki budi bahasa yang sopan, sikap yang ramah tamah, menjunjung tinggi kesetiaan, sangat menjagga perasaan dan menghormati hak orang lain, bangsa Jepang juga taat pada hukum, tata tertip, disiplin dan sangat menghagai waktu dan bersikap jujur. Gemar membaca dan senang menuntut ilmu. Semua hal tersebut sudah menjadi budaya bagi mereka. banyak hal positif yang bisa kita terapkan sebagai pelajaran untuk menjadi bangsa yang berbudaya baik.

\section{Referensi}

1Mulyana, 2006: 18.

2Pujileksono,2015:24-25.

3Liliweri, 2003: 12.

4Dikutip dari Liliweri (2003) dalam Makna Budaya Dalam Komunikasi Antarbudaya.

${ }^{5}$ Mulyana, 2003: 4.
${ }^{6}$ Dikutip dari Deddy Mulyana. 2003.

${ }^{7}$ Mulyana (2006:18)

8Gudykunst dan Kim, 1992: 13

${ }^{9}$ Liliweri, 2003: 7).

10Mulyana dan Rakhmat, 2006:18

11Komunikasi Efektif, 2004: 43.

${ }^{12}$ Fadhli, 2007: 97

13Fadhli, 2007: 97-98.

14Beasley, 2003: 146.

15Mulyana, 2006

16Wawancara dengan Sumiko, UPT Kebahasaan dan Kesenian UNPAD, Selasa, 24 April 2009 jam 10.00 - 11.30 wib.

17Wawancara dengan Mai Namihira, di kantin sakinah, Sabtu, 15 Agustus 2009 jam 17.00 wib.

18http :/ / blogguebo.blogspot.com

${ }^{19}$ Mulyana, 2006

${ }^{20}$ Wawancara dengan Sumiko, UPT Kebahasaan dan Kesenian UNPAD, Selasa, 24 April 2009 jam 10.00 - 11.30 wib.

${ }^{21}$ Wawancara dengan Mai Namihira, di kantin sakinah, Sabtu, 15 Agustus 2009 jam 17.00

Beasley, W. G. 2003. Pengalaman Jepang. Jakarta: Yayasan Obor Indonesia.

Cassirer, Ernst. 1987. Manusia dan Kabudayaan: Sebuah Esai Tentang Manusia. Jakarta: Gramedia.

Danandjaja, James. 1997. Folklor Jepang Dilihat dari Kacamata Indonesia. Jakarta: Pustaka Utama Grafiti.

Endraswara, Suwardi. 2006. Metodologi Penelitian Kebudayaan. Yogyakarta: Gadjah Mada University Press.

Fadhli, Aulia. 2007. Menjadi Pemenang Seperti Bangsa Jepang. Yogyakarta: Pinus Book Publisher.

Fisher, B. Aubrey. 1986. Teori-Teori Komunikasi. Bandung: Remaja Karya.

Kuntowijoyo. 1987, Manusia dan Kebudayaan. Yogyakarta: Tiara Wacana.

Liliweri, Alo. 2003. Makna Budaya Dalam Komunikasi Antarbudaya. Yogyakarta: LkiS.

Mulyana, Deddy \& Rakhmat, Jalaludin. 2006. Komunikasi Antarbudaya. Bandung: Remaja Rosdakarya.

2004. Komunikasi Efektif.

Bandung: Remaja Rosdakarya.

Suatu Pengantar. Bandung: Remaja Rosdakarya.

Reischauer, Edwin O. 1982. The Japanese. Amerika: The Belknap Press of Haervard University Press.

Sudjianto. 2002. Kamus Istilah Masyarakat dan Kebudayaan Jepang. Bekasi-Indonesia: Kesaint Blanc.

Wakaba. 1989. Jepang Dewasa Ini. Tokyo: International Society for Educational Information, Inc. 